\title{
Reversible tongue atrophy in Lambert-Eaton myasthenic syndrome
}

Lauren A. Cammaert, MRCP, Angus D. Macleod, MRCP, PhD, Graham A. Mackay, MRCP, MD, and Callum W. Duncan, MRCP, PhD

Neurology ${ }^{\circledR}$ 2019;93:459-460. doi:10.1212/WNL.0000000000008076

Figure Patient photographs

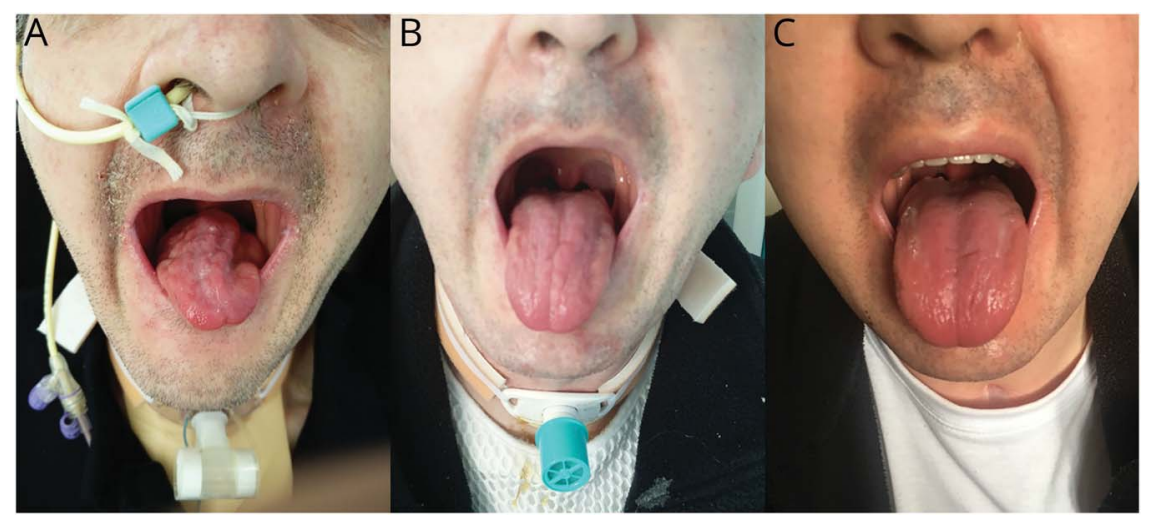

(A) Two months after presentation with Lambert-Eaton myasthenic syndrome, inability to fully protrude tongue and marked bilateral tongue atrophy is evident. (B) Three months later, 2 months after radiotherapy to the patient's small cell lung tumor, only mild atrophy was apparent with a triple furrowed appearance, and (C) normal tongue 10 months after radiotherapy.

A 48-year-old man presented with severe limb, bulbar, and respiratory weakness requiring intubation and ventilation. Decrement was seen on repetitive nerve stimulation, but tested muscles were too weak for voluntary activation and tetanic stimulation was not tolerated. Positive voltage-gated calcium channel and SOX1 antibodies confirmed Lambert-Eaton myasthenic syndrome (LEMS). Despite corticosteroids, 3,4-diaminopyridine, and plasma exchange, severe bulbar weakness persisted, the patient remained tracheostomydependent, and he developed marked tongue atrophy (figure, A). Small cell lung cancer was subsequently confirmed. Radiotherapy 3 months after presentation resulted in recovery of bulbar function, improvement in tongue atrophy, and tracheostomy decannulation with improvement sustained 10 months later (figure, B and C). Tongue atrophy uncommonly occurs in generalized myasthenia gravis ${ }^{1}$ but has not been previously reported in LEMS. The underlying mechanism may be neurogenic atrophy due to severe neuromuscular junction dysfunction. ${ }^{2}$

\section{Author contributions}

L.A. Cammaert: drafting/revising the manuscript, data acquisition, accepts responsibility for conduct of research and final approval, acquisition of data. A.D. Macleod: drafting/revising the manuscript, data acquisition, accepts responsibility for conduct of research and final approval,

\author{
Correspondence \\ Dr. Macleod \\ Angus.Macleod@abdn.ac.uk
}


study supervision. G.A. Mackay: drafting/revising the manuscript, accepts responsibility for conduct of research and final approval, study supervision, review of relevant literature on potential mechanism of muscle atrophy in LEMS. C.W. Duncan: drafting/revising the manuscript, accepts responsibility for conduct of research and final approval, consultant in charge of patient.

\section{Study funding}

No targeted funding reported.

\section{Disclosure}

The authors report no disclosures relevant to the manuscript. Go to Neurology.org/N for full disclosures.

\section{References}

1. De Assis JL, Marchiori PE, Scaff M. Atrophy of the tongue with persistent articulation disorder in myasthenia gravis: report of 10 patients. Auris Nasus Larynx 1994;21: 215-218.

2. Crone C, Christiansen I, Vissing J. Myopathic EMG findings and type II muscle fiber atrophy in patients with Lambert-Eaton myasthenic syndrome. Clin Neurophysio 2013;124:1889-1892.

\section{Disputes \& Debates: Rapid online correspondence}

The editors encourage comments on recent articles through Disputes \& Debates:

Access an article at Neurology.org/N and click on "COMMENT" beneath the article header. Responses will be posted within 3 business days.

Before submitting a comment to Disputes \& Debates, remember the following:

- Disputes \& Debates is restricted to comments about studies published in Neurology within the last eight weeks

- Read previously posted comments; redundant comments will not be posted

- Your submission must be 200 words or less and have a maximum of five references; reference one must be the article on which you are commenting

- You can include a maximum of five authors (including yourself)

\section{Sign Up for the AAN's Axon Registry}

The AAN encourages its US members to show their interest in participating in the Axon Registry by signing up today. Use the Axon Registry to:

- Simplify reporting requirements under MACRA's Quality Payment Program and avoid penalties while reducing your administrative burden

- Meet your MOC Part IV requirements and waive up to eight credits of Part II Self-Assessment

- Choose from 22 AAN neurology-specific quality measures that fit your practice

- Use data to understand your practice and identify where improvements can be made to patient care

- Manage your patients at a population level; look at a specific group of patients based on conditions, risk factors, demographics or outcome

- Demonstrate your value to payers when negotiating reimbursement

- Enjoy multi-year, fee-free access when you sign the agreements and integrate your EHR with the registry

Learn more at AAN.com/view/Axon and send your questions to registry@aan.com. 


\title{
Neurology
}

\author{
Reversible tongue atrophy in Lambert-Eaton myasthenic syndrome \\ Lauren A. Cammaert, Angus D. Macleod, Graham A. Mackay, et al. \\ Neurology 2019;93;459-460 \\ DOI 10.1212/WNL.0000000000008076
}

This information is current as of September 2, 2019

\begin{tabular}{|c|c|}
\hline $\begin{array}{l}\text { Updated Information \& } \\
\text { Services }\end{array}$ & $\begin{array}{l}\text { including high resolution figures, can be found at: } \\
\text { http://n.neurology.org/content/93/10/459.full }\end{array}$ \\
\hline References & $\begin{array}{l}\text { This article cites } 2 \text { articles, } 0 \text { of which you can access for free at: } \\
\text { http://n.neurology.org/content/93/10/459.full\#ref-list- } 1\end{array}$ \\
\hline Subspecialty Collections & $\begin{array}{l}\text { This article, along with others on similar topics, appears in the } \\
\text { following collection(s): } \\
\text { Clinical neurology examination } \\
\text { http://n.neurology.org/cgi/collection/clinical_neurology_examination } \\
\text { Lambert-Eaton syndrome } \\
\text { http://n.neurology.org/cgi/collection/lamberteaton_syndrome } \\
\text { Paraneoplastic syndrome } \\
\text { http://n.neurology.org/cgi/collection/paraneoplastic_syndrome }\end{array}$ \\
\hline Permissions \& Licensing & $\begin{array}{l}\text { Information about reproducing this article in parts (figures,tables) or in } \\
\text { its entirety can be found online at: } \\
\text { http://www.neurology.org/about/about_the_journal\#permissions }\end{array}$ \\
\hline Reprints & $\begin{array}{l}\text { Information about ordering reprints can be found online: } \\
\mathrm{http} / / / \mathrm{n} \text {.neurology.org/subscribers/advertise }\end{array}$ \\
\hline
\end{tabular}

Neurology ${ }^{\circledR}$ is the official journal of the American Academy of Neurology. Published continuously since 1951, it is now a weekly with 48 issues per year. Copyright @ 2019 American Academy of Neurology. All rights reserved. Print ISSN: 0028-3878. Online ISSN: 1526-632X.

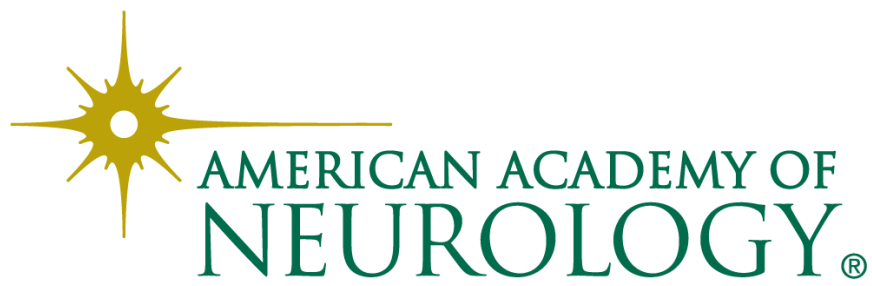

